\title{
Co-operatives and Rural Community Population Growth: Evidence from Canada $^{+}$
}

\author{
Chipo Kangayi, M. Rose Olfert, and Mark Partridge *
}

\begin{abstract}
The social economy holds promise for rural community development through local capacity building, improving political engagement, expanding networks, and increasing productivity by reducing transactions costs. In this study, the contribution of co-op membership to rural community population growth is estimated, along with standard growth determinants. With minor exceptions, the results do not support the expectation that co-ops improve the population growth prospects of rural communities. Currency (or obsolescence) of this particular type of social capital may be a factor. Alternatively, social capital in the form of co-ops may be serving as a substitute for private sector enterprise or other forms of social capital.
\end{abstract}

Key words: Rural Population Growth; Co-operatives

JEL Classifications: R11; R12

\section{INTRODUCTION}

Long-term trends including labor-saving technical change, globalization and urbanization have tended to disadvantage many Canadian rural communities in terms of population growth (Bollman and Mendelson, 1998; Agriculture and Agri-Food Canada, 2002; Rothwell et al., 2002). Past empirical studies have found that rural community growth is positively affected by the development of an amenity-based local economy, close proximity and/or good access to urban agglomeration economies, and other idiosyncratic effects (Deller et al., 2001; Goetz and Rupasingha, 2002; Ferguson et al., 2007; Partridge et al., 2007a).

The social economy is also receiving attention as a factor in community growth and vitality. According to the Organization for Economic Co-operation and Development (2003), the social economy, also referred to as the "third sector" or the "non-profit sector," describes a variety of socio-economic initiatives addressing new opportunities and needs that the private sector and the government do not sufficiently address. ${ }^{1}$ Other researchers such as Quarter (1992) narrowly define the social economy as businesses including co-operatives, credit unions, mutual insurers, not-for profit corporations and unincorporated associations that are governed

\footnotetext{
${ }^{+}$An earlier version of this paper was presented at the Canadian Agricultural Economics Association annual meeting in Portland Oregon, July 2007. We are grateful for the financial support and provision of co-operative data from the Co-operatives Secretariat, Agriculture and Agri-Food Canada. Funding from other partners, particularly The Center for the Study of Cooperatives through a SSHRC (Social Economy) Linking, Learning and Leveraging grant, and the Community University Institute for Social Science Research (CUISR) at the University of Saskatchewan is greatly acknowledged. We thank Bill Reimer and David Freshwater for very helpful comments. We also thank Mike St. Louis, Canada Rural Economy Research Lab (C-RERL) for data geo-coding and mapping of products used in this research.

*Kangayi and Olfert are, respectively, Researcher and Professor at the Department of Bioresources Policy, Business \& Economics, University of Saskatchewan. Partridge is C. William Swank Chair in Rural-Urban Policy and Professor in the Department of Agricultural, Environmental \& Development Economics, The Ohio State University.

Contact author: Mark Partridge, AED Economics, Ohio State University, Columbus, OH, USA; Email: partridge.27@osu.edu.

${ }^{1}$ The term derived from the French term économie sociale is known to have been first recorded about 1900.

(C) Southern Regional Science Association 2010.

SRSA, 1601 University Avenue, PO Box 6025, Morgantown, West Virginia 26506-6025, USA.
} 
democratically by their members or stakeholders to produce and deliver goods and services in the marketplace.

The social economy concept has more recently emerged in Canada. The government of Canada has committed $\$ 132$ million in support of the social economy through capacity building, provision of finance, and research support (HRSDC, 2007). The social economy builds on and produces social capital, social cohesion and relational assets (Gui, 2001; OECD, 2003). SätreÅhlander (2001) proposes that rural development is one of the key areas of interest for the social economy; more specifically, co-operatives may provide a model for rural development. Indeed, she argues that the main factor uniting people in the formation of co-operatives has become the wish to live in a certain region, as opposed to other motivations such as class or profession-based struggles.

Universal empirically-based conclusions regarding the role of the social economy in community economic development have been somewhat elusive for a number of reasons. The means through which the social economy is proposed to exert influence, according to the OECD (2003) definition above, is through building on and producing "social capital, social cohesion and relational assets." Social capital itself is expected to have a positive impact on community resiliency, adaptability and access to networks and resources for local problem-solving (Flora, 1998; Chou, 2006; Birch and Whittam, 2008; Novkovic, 2008). However, it is also argued that major problems of definition have made measurements, and thus rigorous empirical studies, difficult to undertake at best (DeFilippis, 2001; Durlauf, 2002; Birch and Whittam, 2008). ${ }^{2}$ While social capital has proven a prolific area of pursuit in the literature, Durlauf (2002, p. 477) concludes that "observational data to identify substantive forms of social capital is unlikely to be successful," largely because of vagueness in the term. Instead, he argues, economic experiments based on the social psychology literature may be more productive. Glaeser, Laibson, and Sacerdote (2002) point to the successful theory and empirical evidence on the effects of social capital on economic outcomes, noting that the underlying mechanisms that create social capital are largely not understood. On the other hand, if people invest in social capital for purely altruistic reasons, it is sometimes argued that the intended positive outcomes may not be readily quantitatively measurable (Evans and Syrett, 2007; Novkovic, 2008).

Despite definitional and measurement problems, the social economy, especially through the development and use of social capital, has generally been found to have a positive impact on communities (Westlund, 2006). Social capital has been proposed as a key to healthy communities as a result of its positive externalities through improving political engagement, supporting a range of local organizations, building trust and increasing economic productivity (Putnam and Helliwell, 1995; Knack and Keefer, 1997; Rupasingha, Goetz, and Freshwater, 2000). It has been argued that the ability to engage in community development depends in large part upon the existence of social relationships or networks that enable community organization, problem solving, and decision making (Flora, 1998).

However, while social capital and the social economy are generally viewed as having positive externalities for community well being, there is also the possibility of a negative influence. Just as good networks and mutual loyalties can lead to positive outcomes, there is the

\footnotetext{
${ }^{2}$ While the definitional and measurement problems relate to all of social capital, social cohesion, and relational assets, the discussion here is limited to social capital inasmuch as the latter is the most likely way in which co-operative activity will influence community population growth and retention.
}

(C) Southern Regional Science Association, 2010. 
risk that exclusion, discrimination against outsiders, or corruption might also result (Durlauf, 1999; Woolcock, 2000). In a rural development context, Sätre-Åhlander (2001) points out that productive social capital in one era may become non-productive in another if the values and knowledge it is based on become obsolete. She argues that social capital could then actually prevent the development of businesses that operate on the global market, or ones that are capable of adaptation to national and international developments. Glaeser, Kolko, and Saiz (2001), in an empirical study based on an optimal investment model, conclude that social capital accumulation decisions are driven by individual incentives, not group membership. They point to the importance of understanding the externalities generated by social capital investments, concluding that it is not clear whether social capital should be cast as networks with positive externalities or status with negative externalities. Of course, it could be both depending on the particular community or setting.

The intersection of an interest in rural community population growth and co-operatives in Canada is not surprising, since co-operatives have historically had a strong presence in many rural communities (Fowke, 1973; Fulton and Ketilson, 1992). Gaining momentum after 1900, particularly in the prairie region of Canada, early co-ops were formed to address the problems farmers faced regarding control over buying and marketing their inputs and products respectively. Following these early farmer-based co-ops, the co-operative retailing system of Western Canada emerged with roots in the initiatives of rural community-based kinds of cooperatives (Simbandumwe, Murray, and Ketilson, 1991; Fairbairn, 2005). Indeed, for declining rural communities, the local co-operative is commonly viewed as a community stalwart, even in the face of other business exits (Fairbairn et al., 1990; Fulton and Ketilson, 1992).

Co-operative core values and principles emphasize social responsibility and community development, foundations of the social capital within a community (Restakis and Lindquist, 2001). Co-op networks facilitate communication and information flows, mobilize, train and develop community members and leaders, and link the community and its interests to the broader economy. It may thus be reasonable to posit that those rural communities with strong co-op membership may be relatively more attractive locations for households and firms, both in growing and declining rural communities.

In this paper we empirically estimate the role of non-financial co-op membership in the population growth and retention of rural communities in Canada for the 1991-2001 period. Coop membership, as an example of the social economy, is taken to be an indirect influence on community growth and vitality, reflecting the way in which social capital (developed and supported by the social economy) contributes to community well-being and attractiveness for its residents. It is assumed that social capital is embodied in the co-operative institutions. We utilize a unique database provided by the Co-operative Secretariat of Agriculture and Agri-food Canada on the presence and type of co-operatives geo-coded to a very fine level of detail. These data, along with a rich database of detailed community characteristics, including amenities and spatial identifiers, are used to assess the marginal impact of the presence of co-ops in rural community population growth. In sum, these unique data allow us to conduct what we believe to be the first national-level assessment of the role of cooperatives on community-level growth. The findings do not generally support the expectation that community population growth is positively affected by a higher co-op membership of the residents.

This paper is organized as follows. The next section presents an overview of co-ops in Canada, followed by the theoretical framework that will inform the empirical analysis. Section 4

(C) Southern Regional Science Association, 2010. 
contains the empirical model. The results are presented in Section 5, followed by conclusions and policy implications.

\section{THE CO-OPERATIVE SECTOR IN CANADA}

In Canada, a co-operative is an enterprise that is jointly owned by the members who use its services. All members of a co-op are equal decision makers in the enterprise, using a democratic system of one member, one vote. In turn, all members share the benefits of cooperation, based on how much they use the co-operative's service (AAFC 2008). ${ }^{3}$ A co-operative is a legal entity, normally incorporated under a provincial co-operative statute setting out its corporate form and mode of operation. ${ }^{4}$

The co-operative movement found its way into Canada in the $1860 \mathrm{~s}$, with "the well-to-do and the intellectuals" developing co-operative societies to help "the poor and the ignorant" escape from the socio-economic ills which industrialization and urbanisation had brought upon them (MacPherson, 1979). The roots of consumer co-ops were found in mutual insurance organizations formed by farmers and co-operative stores in mining communities across the country between the $1860 \mathrm{~s}$ and 1880s. The first era of these user co-operatives began in Stellarton, Nova Scotia, in 1861 (Quarter, 1992; Birchall, 1997). Later, a series of other smaller consumer co-ops spread to mining districts in the provinces of British Columbia and Alberta and to the larger cities of Halifax, Montreal, Winnipeg and Toronto (McPherson, 1979). Early agricultural dairy, poultry, and egg co-ops in Ontario and Quebec were short-lived (Birchall, 1997).

Co-ops serving the farming community, especially in Western Canada, were founded in the early 1900s as farmers tried to counter large corporations in both the marketing of their products and buying inputs. The greatest progress was made in Prairie grain marketing, through the emergence of grain growers associations ${ }^{5}$ in 1906 ; by the turn of the $20^{\text {th }}$ century, this group overshadowed the early revolutionary movement by urban workers (Fairbairn, 1990).

The equivalent of German credit co-operatives emerged in Canada to address problems of lack of credit support for urban working class citizens. Alphonse Desjardins started the first credit co-operative in Quebec City in 1900. While these co-ops later spread to other parts of Canada, most credit unions, especially in western Canada, were created after 1944 (MacPherson, 1979; Fairbairn, 1990; Craig, 1993).

Canadian worker co-ops are similar to "generic" co-ops in the U.S. in that they are "member owned" but the members/owners are also the employees. This characteristic distinguishes these from the European worker co-ops, which were consumer co-ops formed by "workers." Unlike the consumer co-ops formed by British workers, these Canadian worker coops never became an integral part of the Canadian working class. According to Fairbairn (1990), the major disincentive was the sparse concentration of urban workers, as well as the demographic heterogeneity in the working class structures.

\footnotetext{
${ }^{3}$ More detail at Canada's official website for its Co-operatives Secretariat <www.coop.gc.ca>. This definition is very similar to that in the U.S., where a co-operative is defined as a user-owned and user-controlled business that distributes benefits on the basis of use. The user is the member of the co-operative who has a financial investment in the co-operative, controls the co-operative by exercising a one member, one vote policy, and receives benefits in proportion to use (University of Wisconsin 2005).

${ }^{4}$ Federal incorporation is possible if the co-operative is carrying on its business in two or more provinces, and has a fixed place of business in more than one province.

${ }^{5}$ The Grain Growers Company was the biggest of these grains growing associations and later became known as United Grain Growers; the latter in turn became part of Agricore United in 2001.
}

(C) Southern Regional Science Association, 2010. 
Housing co-ops, which can be traced back to the early 1970s, originated as a way to increase affordable housing, particularly in Toronto and Vancouver. They were largely enabled by an amendment to the Housing Act $^{6}$ in 1973 that allowed non-profit corporations to access loans to start house building projects. These funding opportunities, however, ceased in 1996. Other health and social care co-ops such as day care and community co-ops are most prominent in Quebec (Birchall, 1997).

In Canada there is a regional dimension in co-op development. For instance, Quebec has the fastest-growing worker housing and consumer co-ops. Saskatchewan has developed one of the most powerful co-operative sectors, mostly consumer and agriculture marketing co-ops, attributable to the degree of government support extended to co-operatives in terms of leadership, advice, and legislation (Quarter, 1992; Fairbairn, 2001). In general, Canada has the most co-operative economy in the Americas, with close to 7,000 co-operatives (including financial co-operatives) and a total membership of over 21 million, translating into about 700 coop memberships per 1,000 population.

Among the non-financial co-operatives in Canada, consumer co-ops comprise the largest share, accounting for 69 percent of all co-ops, followed by producer co-ops at 19 percent. The average age of the co-ops themselves varies by type: producer co-ops are the oldest (50 yrs.); consumer co-ops have an average age of 43 with worker co-ops the youngest with an average age of 27. By industry agriculture co-ops have an average age of 53 followed closely by retail co-ops at an average age of 51, with housing co-ops being the youngest at 26 years. Thus, there should be sufficient regional heterogeneity among the co-ops to be able to detect different community outcomes, if co-op intensity does indeed have an influence.

Spatial differences in the concentration of co-operatives is evident in Appendix Figure 1, which shows the co-ops (all types, except financial) across Canada. Clearly the co-ops are widely distributed throughout rural areas of the Prairie region and to a lesser extent in Atlantic Canada, while being largely absent in northern Ontario and Quebec as well as interior British Columbia. In southern Quebec and Ontario, the co-op presence appears closely correlated with the distribution of urban centers.

The Canadian Prairies, located in the northern portion of the Great Plains region of North America, are characterized by an extensive agricultural base that has experienced labor-reducing technical change. The long distance from major markets has limited the growth of new economic activities that would utilize the surplus labor, thus leading to long-term population declines in the resource-based rural areas. As shown in Appendix Figure 1, this region has strong co-op membership throughout its rural areas, a pattern also evident to some extent in the Atlantic region. It is thus important to test whether those rural communities with higher co-op membership are better able to withstand economic decline, or facilitate the development of new economic bases that would support a local population.

\section{POPULATION GROWTH THEORETICAL FRAMEWORK}

Our metric of community health and vitality is the community's ability to retain and attract population through net migration. Thus, community health is reflected in having differential equilibrium long-run population growth rates. Along with other standard population

\footnotetext{
${ }^{6}$ The Housing Act, first passed in 1938, provided support by way of low interest mortgages. Political opposition led to the discontinuation of this support, but it was reinstated in the 1970 s.
}

(C) Southern Regional Science Association, 2010. 
retention/growth determinants, the association between co-op intensity and community population growth will be assessed, in which we assume that co-operative intensity reflects a form of social capital.

Our theoretical framework follows Roback (1982) and subsequent literature (e.g. Voith, 1991; Partridge et al., 2007a,b). Community-level population growth reflects a host of location decisions by firms and households (Partridge and Rickman, 2003). ${ }^{7}$ First, a community's economic strength relates to whether the region's mix of industries is faring well nationally (Partridge and Rickman, 1996; Simon, 1998). Agglomeration economies have also been shown to have a strong influence (Krugman, 1991). Growth will likewise be influenced by access to urban amenities available in higher-tiered urban areas (Glaeser, Kolko, and Saiz, 2001). Natural amenities such as a clean environment, beautiful vistas, and abundant recreation opportunities are also likely to increase rural community population growth (Deller et al., 2001; McGranahan and Beale, 2002; Ferguson et al., 2007).

The roles of social capital/cohesion have also been found to be instrumental in explaining the relative success of some North American communities. Social capital is purported to result in reduced transactions costs, and thus higher productivity and better economic growth prospects (Putnam, 1993; Flora, 1998; Kilkenny, Nalbarte, and Besser 1999; Turcotte 2005). These effects are seen as positive externalities of efficient social organization and/or strong networks built on mutual trust and common norms (Durlauf and Fafchamps, 2004; Chou, 2006; Birch and Whittam, 2008). (Amen):

Households locate to maximize utility in consuming traded goods $(X)$ and amenities

$$
U_{k}=U_{k}\left(X_{k}, \text { Amen }_{k}\right),
$$

where $k$ denotes the community of residence. Access to traded goods will be a function of income, including wages, $w_{k}$. The cost of accessing amenities and goods and services outside the community is constrained by the distance between communities $k$ and $j\left(d_{k j)}\right.$; the consumption of traded goods is also constrained by the budget.

The level of social capital in community $k\left(S o C_{k}\right)$ contributes to the quality of life, partially through the consumption of amenities, as well as through reduced transactions costs in finding employment and improving productivity. Based on the developing literature, social capital can perform a facilitative role in quality of life considerations and in both accessing amenities and in employment opportunities (Putnam and Helliwell, 1995; Flora, 1998; Chou, 2006; Birch and Whittam, 2008). In our case, we are assessing whether social capital, as manifested through co-op intensity, can perform this role. Therefore, the resulting indirect utility function can be written as:

$$
V_{k}=V_{k}\left(\text { Amen }_{k}, S_{o} C_{\boldsymbol{k}}, w_{k}, d_{k j}\right) \text {. }
$$

Utility is higher where there is better access to arrays of employment and amenities.

When the expected utility is different across communities, households will move from relatively low-utility communities to those with higher expected utility, subject to moving costs.

\footnotetext{
${ }^{7}$ While it is community population change that is of primary interest, the discussion and framework focuses on the net migration determinants inasmuch as it is this component that is most responsive to changing economic conditions and other community characteristics. Partridge and Rickman (2003) show that population and migration are highly correlated, which is why many migration studies use population change.
}

(C) Southern Regional Science Association, 2010. 
Interregional equilibrium implies equalized utility across space, though adjustments to both demand and supply shocks may occur more or less continuously. Further, information constraints and moving costs mean that migration may only partially adjust in a given period to utility differentials. Thus, net migration $(N M)$ into community $k$ in a representative period relates to the difference in expected household utility between community $k$ and the average of all other communities $\left(\bar{V}_{R}\right)$ :

$$
N M_{k}=\alpha_{k}\left(V_{k}-\bar{V}_{R}\right), 0 \leq \alpha_{k} \leq 1,
$$

where $\alpha$ is the adjustment rate.

A reduced form equation for population growth can be derived from Equations 1-3. Population growth in both community $k$ (and other potential locations) is related to the levels of amenities (both natural and urban based), the level of agglomeration economies (Agglom), the underlying local economic and demographic structure (Econ), the stock of social capital, and distances between the communities:

$$
\operatorname{PopGr}_{k}=h_{i}\left(\text { Amen }_{k}, \operatorname{Agglom}_{k}, \text { Econ }_{k}, \text { SoC }_{k}, d_{i j}\right) .
$$

\section{EMPIRICAL IMPLEMENTATION}

The change in population between 1991 and 2001 is expressed as a function of 1991 agglomeration, other economic/demographic, amenity, and co-op membership characteristics:

$$
\% \Delta \mathbf{P}_{2001-1991}=f\left(\text { Agglom }_{1991}, \text { Econ }_{1991}, \text { Amen }_{1991}, \text { SoC }_{1992}, \mathbf{p d}, \mathbf{e}\right) .
$$

This specification of population change being influenced by pre-existing (1991) conditions helps mitigate problems of statistical endogeneity.

Agglom is a vector containing variables that represent the influence of local agglomeration economies, or access to those in nearby urban centers. These include the size of the nearest (or own) Census Metropolitan Area (CMA), own community population as well as that of the surrounding communities, and distances to urban areas of different sizes (to represent access to agglomeration economies).

The Econ vector includes pre-existing community economic and demographic conditions, including the employment rate, industry structure (share of employment in agriculture, other primary industry, and manufacturing), and self-employment as a percent of nonfarm employment to represent entrepreneurship. A high initial employment rate will, all else constant, make the community a more attractive location for households. Industry structure is important because some industries are growing more rapidly at the national level. ${ }^{8}$ Also included in the Econ vector are: the population share with an aboriginal ancestry and the percentage of population over 15 years old with a university degree. ${ }^{9}$ Aboriginal share of the population is expected to have a positive effect through natural increase, inasmuch as the rate of natural increase among the Aboriginal population remains relatively high (Bollman, 2006). Education has an ambiguous effect on population growth. Higher levels of education are expected to result

\footnotetext{
${ }^{8}$ Preliminary investigations also included the initial 1991 share below the low income cutoff (or a 'poverty rate'), the unemployment rate, and per capita total income, but these were not included in the final specification due to multicolliniarity.

${ }^{9}$ Initially human capital was represented by the percentage that falls into six education attainment categories (individuals with less than grade 9 to those that have a graduate degree) but only the university degree was retained.
}

(C) Southern Regional Science Association, 2010. 
in higher productivity levels, making the community attractive to firms. If they, however, result in higher labor costs they may dampen the community's attractiveness for businesses.

The Amen vector is a combination of climate/weather characteristics and "built" amenities. Among the climate/weather variables, only July relative humidity and the average January temperature are included in the final specification. For built amenities we considered the per capita number of police stations, acute care hospitals, cinemas, golf courses, long term acute care hospitals, outpatient clinics, educational institutions and tourism sites, as well as their respective distance measures. Of these, only the per capita number of outpatient clinics and number of cinemas were adopted for the final base model after taking into account multicollinearity and explanatory value.

Of major interest in our investigation is the SoC vector representing the role of social capital in community population growth. While recognizing that there remain outstanding definitional issues regarding the relationship between social capital and the social economy, as well as social capital and co-ops (Evans and Syrett, 2007; Birch and Whittam, 2008; Novkovic, 2008) we use co-op involvement as a representation of the potential role of social capital in community well-being. Initial investigations included the per capita number of co-ops within a community as well as some spatial co-op variables such as co-ops within $100 \mathrm{~km}$ or $200 \mathrm{~km}$, fulltime or part-time co-op employment, communities, and per capita assets of the co-operatives. Out of the broad set of co-operative variables that we explored for possible explanatory power, given the high degree of multicollinearity, the per capita co-op membership and membership from the surrounding communities were chosen to represent the intensity of co-op activity in the community. ${ }^{10}$ Using per capita membership identifies the extent or intensity to which the community population is involved in co-op activity rather than reflecting the size of the co-op itself. ${ }^{11}$ One of the innovative elements of the analysis is the assessment of whether co-ops of different types (worker, consumer, and producer), in different regions, or in different industries (agriculture, retail, and service co-ops) have distinct effects on their community population growth.

Provincial dummy variables $(p d)$ control for factors that vary by province, such as differences in legislation or regulation, especially with respect to co-operatives. Thus, the explanatory variables are measuring how changes within a province affect relative community growth. The error term, assumed to be normally distributed, is included as $e$. We use the Stata cluster command to adjust for spatial autocorrelation of the error terms within each Census subdivision (see the notes to Table 1).

Co-operative activity seems to be prevalent in rural areas, and some studies have clearly indicated that social enterprises, particularly co-ops, may have allowed many small rural communities to partially offset decline (Fulton and Ketilson, 1992; Reimer, 1997). For these reasons our model was estimated separately for rural and urban communities by classifying areas as "rural" if they do not geographically overlap part of a census metropolitan area (CMA), or a

\footnotetext{
${ }^{10}$ Surrounding CCA attributes are used to capture spillovers (e.g. per capita membership of nearby communities).

${ }^{11}$ While co-op sizes vary over time, across types, and by location, our study includes no multi-province co-ops and that the rapid consolidation in the Co-ops sector evident in the U.S. over the past 20 years or so has not happened in Canada to nearly the same extent. Further, the New Generation type of co-op which has gained a major foothold in the U.S. is very uncommon in Canada. In Canada, the co-ops remain largely locally owned for the benefit of local memberships. For example, while technically possible, co-ops do not operate in communities other than where their owners reside/patronize the co-op.
}

(C) Southern Regional Science Association, 2010. 


\section{TABLE 1. Rural and Urban Percentage Change in Population} for 1991-2001 Base Model Results ${ }^{\mathrm{a}, \mathrm{b}}$

\begin{tabular}{|c|c|c|}
\hline Explanatory Variable $^{c}$ & Rural Model & Urban Model \\
\hline Distance to nearest CMA, pop. $100 \mathrm{k}$ & $\begin{array}{r}-0.0002 * * * \\
(-4.01)\end{array}$ & $\begin{array}{r}-0.00029 * * * \\
(-4.32)\end{array}$ \\
\hline Incremental distance to CMA, pop. $250 \mathrm{k}$ & $\begin{array}{r}-0.00007^{*} \\
(-1.66)\end{array}$ & $\begin{array}{r}-0.00011^{* *} \\
(-2.29)\end{array}$ \\
\hline Incremental distance to CMA, pop. $500 \mathrm{k}$ & $\begin{array}{r}-0.00023 * * * \\
(-2.85)\end{array}$ & $\begin{array}{r}0.00009 \\
(0.58)\end{array}$ \\
\hline Nearest or own CMA population, 1991 & $\begin{array}{r}1.64 \mathrm{E}-08^{* *} \\
(2.18)\end{array}$ & $\begin{array}{r}1.52 \mathrm{E}-08^{* *} \\
(2.35)\end{array}$ \\
\hline Pop. of surrounding CCSs 1991 & $\begin{array}{r}2.80 \mathrm{E}-07 * * * \\
(3.93)\end{array}$ & $\begin{array}{r}-9.46 \mathrm{E}-09 \\
(-0.84)\end{array}$ \\
\hline Population of the CCS, 1991 & $\begin{array}{r}5.44 \mathrm{E}-07 \\
(0.51)\end{array}$ & $\begin{array}{r}-8.02 \mathrm{E}-08 \\
(-1.61)\end{array}$ \\
\hline Co-op membership per capita & $\begin{array}{r}-0.00879 \\
(-1.02)\end{array}$ & $\begin{array}{r}-0.01513 \\
(-0.48)\end{array}$ \\
\hline Co-op membership per capita, nearby CCSs & $\begin{array}{r}-0.03992 * * \\
(-2.04)\end{array}$ & $\begin{array}{r}0.03688 \\
(0.92)\end{array}$ \\
\hline Employment rate & $\begin{array}{r}0.25442 * * * \\
(5.70)\end{array}$ & $\begin{array}{r}0.3441 * * * \\
(3.93)\end{array}$ \\
\hline Agriculture share of employment & $\begin{array}{r}-0.41137 * * * \\
(-7.32)\end{array}$ & $\begin{array}{r}-0.4468 * * \\
(-2.21)\end{array}$ \\
\hline Other primary share of employment & $\begin{array}{r}-0.52944 * * * \\
(-4.89)\end{array}$ & $\begin{array}{r}0.21609 \\
(0.83)\end{array}$ \\
\hline Manufacturing share of employment & $\begin{array}{r}-0.26696 * * * \\
(-3.50)\end{array}$ & $\begin{array}{r}0.9266 \\
(0.4)\end{array}$ \\
\hline$\%$ nonfarm self employment & $\begin{array}{r}0.06685 \\
(0.73)\end{array}$ & $\begin{array}{r}0.5148^{* *} \\
(2.11)\end{array}$ \\
\hline$\%$ with university degree & $\begin{array}{r}0.09429 \\
(0.5)\end{array}$ & $\begin{array}{r}-0.07118 \\
(-0.46)\end{array}$ \\
\hline$\%$ of aboriginal origin & $\begin{array}{r}0.15736^{*} \\
(1.68)\end{array}$ & $\begin{array}{r}0.32286^{* *} \\
(2.05)\end{array}$ \\
\hline July relative humidity & $\begin{array}{r}-0.00003 \\
(-0.09)\end{array}$ & $\begin{array}{r}0.00093^{*} \\
(1.98)\end{array}$ \\
\hline January average temperature & $\begin{array}{r}0.00262^{* *} \\
(2.61)\end{array}$ & $\begin{array}{r}-0.0021^{*} \\
(-1.97)\end{array}$ \\
\hline Cinemas per capita & $\begin{array}{r}334.43^{*} \\
(1.95)\end{array}$ & $\begin{array}{r}34.69 \\
(0.9)\end{array}$ \\
\hline Outpatient clinics per capita & $\begin{array}{r}10.40 \\
(0.63)\end{array}$ & $\begin{array}{r}-133.53 \\
(-0.76)\end{array}$ \\
\hline Constant & $\begin{array}{r}-0.02004 \\
(-0.33)\end{array}$ & $\begin{array}{r}-0.20068^{* *} \\
(-2.56)\end{array}$ \\
\hline Observations & 1995 & 510 \\
\hline $\mathrm{R}^{2}$ & 0.3163 & 0.4786 \\
\hline
\end{tabular}

Notes: ${ }^{a}$ Northern Territories are excluded from the sample; Robust $t$-statistics in parentheses. To adjust for spatial autocorrelation, $t$-statistics are adjusted for the clustering of the error terms within a given Census Division (CD). CDs are 288 regions (in 1996), containing 10 CCSs on average. *, **, and $* * *$ denote significance at $10 \%, 5 \%$, and $1 \%$ respectively. $\mathrm{X}$ denotes that provincial dummies are included in the model; ${ }^{b}$ See Appendix Table 1 for variable definitions. 
census agglomeration (CA). ${ }^{12}$ Of the 2,601 communities in all of Canada, 2,086 are rural and 515 urban.

\subsection{Data Sources}

Population data and other socio-economic variables were obtained from the 1991 and 2001 Statistics Canada Census of Population. Additional data sources, described in Appendix Table 1, include Environment Canada, DMTI database, the Data Library Initiative (DLI), and the Canada Rural Economy Research Lab (CRERL). All the data are aggregated to the Census Consolidated Subdivision (CCS) level, which represent communities for our purposes. ${ }^{13}$

Data for co-operative activity variables are obtained from the Co-operative Secretariat of Agriculture and Agri-Food Canada. Two types of data sets were used. First, we accessed a dataset from which the Co-operative Secretariat collects information on all registered cooperatives such as status of co-operatives (whether they are still functional or not), the year in which the co-operative was begun, and their types. The second dataset was derived from the annual mail survey of co-operatives with data on co-operative membership, employment, sales and asset endowments; the survey has a 75 percent response rate.

\section{RESULTS}

Descriptive statistics presented in Appendix Table 2 show that the average rural CCS lost 0.9 percent of its population between 1991 and 2001, with a much steeper decline of about 2.4 percent between 1996 and 2001. In these two time frames, the average growth in urban CCSs was 11 percent and 3 percent respectively. Another indicator of the relative economic strength of the two types of communities is the employment rate of 76 percent for urban areas compared with 56 percent for rural areas. Rural communities have a higher membership in co-operatives compared to urban CCSs. Based on co-op membership, the population affiliated with a co-op is 11 percent for rural communities and 6 percent for urban communities.

\subsection{Base Model Regression Results-All Co-ops}

Table 1 presents the base model results for rural and urban communities. The key co-op activity variables are represented as the per capita co-op membership in the CCS as well as in the surrounding CCSs. ${ }^{14}$ Per capita co-op membership in the community, however, does not have a significant influence on population change in either rural or urban communities. Co-op membership in surrounding communities is also insignificant for urban communities, but highly significant and, contrary to expectations, a negative influence for rural communities. To the extent that co-op membership represents a community's social capital, these results do not reveal a positive influence of social capital on community population growth. However, the results

\footnotetext{
${ }^{12}$ According to Statistics Canada, a census metropolitan area (CMA) or a census agglomeration (CA) is an area consisting of one or more adjacent municipalities situated around a major urban core. To form a CMA, the urban core must have a population of at least 100,000. To form a CA, the urban core must have a population of at least 10,000. Available at: http://www12.statcan.ca/english/census01/Products/Reference/dict/geo010.htm.

${ }^{13}$ Statistics Canada defines a Census Consolidated Subdivision (CCS) as a grouping of adjacent census subdivisions. Generally urban census subdivisions (towns, villages, etc.) are combined with the surrounding, larger, more rural census subdivision, in order to create a geographic level between the census subdivision and the census division.

${ }^{14} \mathrm{We}$ experimented with various measures of co-ops and co-op activity to represent the size and strength of the co-ops in the community. These included the number of co-ops within a community, the share of people engaged in full-time or part-time coop employment, the value of co-op assets, as well as the sales volumes generated by the various co-op types; for example, consumer co-ops. The alternative measures did not yield statistically significant results and thus we use the per capita membership as the dependent variable as conceptually it most clearly reflects community population involvement in co-op activity.
}

(C) Southern Regional Science Association, 2010. 
could be reflecting a great deal of heterogeneity by region, co-op type, or industry, such that offsetting significant impacts within the groups may be masked by the aggregate measures. Thus, in the next section we estimate the models for by co-op type, and then by region and industry.

The co-op impact results must be understood in the context of other factors affecting population growth and retention. Thus, following Partridge et al. (2007a, 2007b, 2008), the first three variables describe the effect of the community's remoteness from successively larger urban centers. The first variable is distance from a CMA, that is, an urban community with a core population of at least $100 \mathrm{~K}$. The other two variables are then the incremental distances for accessing goods and services or employment in successively larger urban centers, first 250-500K and then $500 \mathrm{~K}+$. For both rural and (smaller) urban communities, remoteness from larger centers has a consistently significant and negative effect on population growth. For instance, each additional kilometer from the core of the nearest CMA (urban center of 100K), resulted in a reduction in rural community population growth of about 0.022 percentage points. At the mean distance of 139 kilometers, this translates into a penalty of 3.1percent less growth. The actual size of the negative effect is largest for the incremental distance from the largest category centre of $500 \mathrm{~K}+$.

The three population size variables reveal the impact of scale considerations, both of the community itself and nearby urban communities. First, the size of the nearest CMA has a strong positive effect on population growth for rural CCSs, as well as urban CCSs. Second, for rural communities, the size of the aggregated populations of surrounding CCSs also exerts a positive and significant influence. These effects underline the importance of access to urban agglomeration economies and nearby markets for rural communities. The rural community's own population, however, is not statistically significant because regional effects are so dominant.

With regard to the economic variables, we find the impact of the employment rate was positive as expected for both samples. The share of people employed in the agriculture sector is inversely related to population growth, as was the case for the share of people employed in the other-primary sector. The negative effect of "\% manufacturing" may be attributable to increased productivity growth.

Education levels, represented by the proportion of the labor force that has a university degree, are statistically insignificant in both the rural and urban samples. A possible explanation is that the role of education may be absorbed in some of the other variables such as the employment rate or industry structure. The share of the population that is of aboriginal origin is positive and significant for both the rural and urban samples, probably reflecting higher rates of natural increase (Bollman, 2006). Finally, there is a somewhat mixed pattern regarding the influence of the amenity variables, with July humidity being positive in urban areas and insignificant in rural and January temperatures apparently exerting a negative positive in urban areas and a positive influence in rural.

\subsection{Co-op Activity by Co-op Type}

Our data on co-ops allowed us to divide co-operatives into consumer, producer, worker, multi-stakeholder, and federation and wholesale types. ${ }^{15}$ Because the latter three had very low

\footnotetext{
${ }^{15}$ A consumer co-op provides products or services to its members (such as a retail, housing, health-care, or child-care co-op); A producer co-op processes and markets the goods or services produced by its members, and/or supplies products or services necessary to the members' professional activities (such as independent entrepreneurs, artisans, or farmers); A worker co-op provides employment for its members. In this type of co-op, the employees are the members and the owners of the enterprise; a multi-stakeholder co-op serves the needs of different stakeholder groups - such as employees, clients, and other interested
}

(C) Southern Regional Science Association, 2010. 
numbers, they were combined into a single category that we will refer to as "other" co-ops. Consumer co-ops make up the bulk of the co-operatives, 2,863 of the 3,633 total co-ops in the study. These co-ops, owned by their customers, provide services to households such as retail services, health care, and housing. Membership in consumer co-ops constitutes more than 80 percent of the total members $(1,961,189$ of 2,334,919). The 615 producer co-ops are owned mostly by farmers to process and/or to market their products. Producer co-ops may also provide supplies or services for their members.

Worker co-ops are owned by employee members and may be found in all economic sectors, but at 106 in number, they are less common than other types of co-ops. They are most prevalent in the forestry industry. The last category, comprised of the combined wholesale (4), federations (42) and multi-stakeholder co-ops (3), are basically co-ops whose membership includes different categories of members who share a common interest in the organization. That is, a variety of stakeholders unite their efforts to provide a service. For instance, wholesale coops give their local co-ops the benefit of mass buying.

Results by co-op type, presented in Table 2, show that in neither rural nor urban communities do we find membership in worker or producer co-ops positively influencing population growth. Nor are there positive neighborhood effects accruing from worker and producer co-op membership in the surrounding communities. Producer co-operatives in rural communities may have been formed to offer solutions to various producer marketing and inputsupply problems at the beginning of the $20^{\text {th }}$ century, while worker co-ops are a much more recent development. In either case, the current role of these co-ops in their communities appears to be independent of factors that would attract population to their communities, or mediate declines in those rural resource-dependent communities experiencing long term declines.

Community consumer co-op membership, accounting for more than half of all co-op membership in Canada, is insignificant in rural community population growth, and negative and significant in urban communities. The results do not support a positive role for these cooperatives in providing retail, health care or housing services, in community population growth, or in retention over the period under investigation. While these co-ops, as a form of social capital in their communities, may perform functions for their memberships, their role is not one that translates into improved population growth or retention. Consumer co-op membership in surrounding communities has a positive influence on rural community population growth, suggesting the possibility of some positive regional spillovers.

Unlike other co-op types, we observe positive and significant effects of per capita membership in the "other" co-ops category on rural community population growth. However, given the heterogeneous nature of this group and the small numbers (49 aggregated), these results must be treated with caution.

\subsection{Co-op Activity by Region and Industry Category}

There is a possibility that the broader economic regions in the country represent fundamentally different settings for economic growth, and thus perhaps for the role of co-ops. In this regard we conducted an analysis of the determinants of population growth by dividing the

individuals and organizations. This type of co-op is usually found in health, home care and other social enterprises. Source: http://www.agr.gc.ca/rcs-src/coop/index_e.php?s1=info_coop\&page=what-quoi.

(C) Southern Regional Science Association, 2010. 


\section{TABLE 2. Determinants of Rural and Urban Percentage Population Change} for 1991-2001 by Co-op Typa ${ }^{a, b}$

\begin{tabular}{|c|c|c|c|c|c|c|c|c|}
\hline \multirow{2}{*}{$\begin{array}{l}\text { Explantory } \\
\text { Variables }\end{array}$} & \multicolumn{4}{|c|}{ Rural (1,994 observations) } & \multicolumn{4}{|c|}{ Urban (510 observations) } \\
\hline & Consumer & Producer & Worker & Other & Consumer & Producer & Worker & Other \\
\hline Distance to nearest CMA, & $-0.0002 * * *$ & $-0.0002 * * *$ & $-0.0002 * * *$ & $-0.0002 * * *$ & $-0.0003 * * *$ & $-0.0003 * * *$ & $-0.0003 * * *$ & $-0.0003^{* * *}$ \\
\hline pop. $100 \mathrm{k}$ & $(-4.04)$ & $(-4.12)$ & $(-4.00)$ & $(-4.26)$ & $(-3.68)$ & $(-4.32)$ & $(-4.37)$ & $(-4.37)$ \\
\hline Incremental distance to & $-0.00007 *$ & $-0.00008^{*}$ & -0.00008 & $-0.00008 *$ & $-0.00011 * *$ & $-0.0001 * *$ & $-0.00011 * *$ & $-0.0001 * *$ \\
\hline CMA, pop. $250 \mathrm{k}$ & $(-1.69)$ & $(-1.75)$ & $(-1.66)$ & $(-1.74)$ & $(-2.57)$ & $(-2.21)$ & $(-2.23)$ & $(-2.23)$ \\
\hline Incremental distance to & $-0.00024 * * *$ & $-0.0002 * * *$ & $-0.00022 * *$ & $-0.0002 * * *$ & 0.0001 & 0.00009 & 0.00008 & 0.00009 \\
\hline CMA, pop. $500 \mathrm{k}$ & $(-2.78)$ & $(-2.72)$ & $(-2.62)$ & $(-2.75)$ & $(0.6)$ & $(0.56)$ & $(0.46)$ & $(0.57)$ \\
\hline Nearest or own CMA & $5.50 \mathrm{E}-07 * *$ & $5.2 \mathrm{E}-07 * *$ & $5.1 \mathrm{E}-07 * *$ & $1.67 \mathrm{E}-08 * *$ & $1.51 \mathrm{E}-08 * *$ & $1.48 \mathrm{E}-08 * *$ & $1.47 \mathrm{E}-08 * *$ & $1.50 \mathrm{E}-08 * *$ \\
\hline Population, 1991 & $(2.19)$ & $(2.17)$ & $(2.16)$ & $(2.22)$ & $(2.34)$ & $(2.29)$ & $(2.30)$ & $(2.30)$ \\
\hline Population of surrounding & $2.3 \mathrm{E}-07 * * *$ & $2.8 \mathrm{E}-07 * * *$ & $2.8 \mathrm{E}-07 * * *$ & $2.73 \mathrm{E}-7 * * *$ & $-9.22 \mathrm{E}-09$ & $-8.13 \mathrm{E}-09$ & $-7.94 \mathrm{E}-09$ & $-8.56 \mathrm{E}-09$ \\
\hline CCSs 1991 & $(3.97)$ & $(3.90)$ & $(3.88)$ & $(3.72)$ & $(-0.76)$ & $(-0.74)$ & $(-0.76)$ & $(-0.75)$ \\
\hline \multirow{2}{*}{ Population of the CCS, 1991} & $5.50 \mathrm{E}-07$ & $5.21 \mathrm{E}-07$ & $5.10 \mathrm{E}-07$ & 4.93E-07 & $-7.96 \mathrm{E}-08$ & $-7.03 \mathrm{E}-08$ & $-7.94 \mathrm{E}-09$ & $-7.54 \mathrm{E}-08$ \\
\hline & $(0.51)$ & $(0.48)$ & $(0.47)$ & $(0.46)$ & $(-1.46)$ & $(-1.52)$ & $(-1.53)$ & $(-1.52)$ \\
\hline Consumer co-op & -0.0107 & & & & $-0.0968 * * *$ & & & \\
\hline membership per capita & $(-1.04)$ & & & & $(-2.95)$ & & & \\
\hline Consumer co-op/capita & $0.03908 *$ & & & & -0.46498 & & & \\
\hline surrounding CCSs & $(\mathbf{1 . 7 5 )}$ & & & & $(-0.68)$ & & & \\
\hline Producer co-op & & -0.01099 & & & & $-0.2247 * * *$ & & \\
\hline membership per capita & & $(-0.73)$ & & & & $(-3.90)$ & & \\
\hline Producer co-op/capita & & -0.00376 & & & & 0.13598 & & \\
\hline surrounding CCSs & & $(-0.05)$ & & & & $(\mathbf{0 . 8 2})$ & & \\
\hline Worker co-op membership & & & 0.02953 & & & & -5.08822 & \\
\hline per capita & & & $(0.47)$ & & & & $(-1.27)$ & \\
\hline Worker co-op/capita & & & $-0.8454 * *$ & & & & -0.20686 & \\
\hline surrounding CCSs & & & $(-2.54)$ & & & & $(-0.12)$ & \\
\hline Other co-op membership & & & & $4.9578 * * *$ & & & & 0.0204 \\
\hline per capita & & & & (3.44) & & & & $(0.19)$ \\
\hline Other co-op/capita & & & & $1.48998 * * *$ & & & & -0.01287 \\
\hline surrounding CCSs & & & & (4.19) & & & & $(-0.25)$ \\
\hline \multirow[t]{2}{*}{ Employment rate } & $0.2552 * * *$ & $0.2542 * * *$ & $0.2531 * * *$ & $0.2524 * * *$ & $0.3413 * * *$ & $0.3463 * * *$ & $0.3415 * * *$ & $0.3422 * * *$ \\
\hline & $(5.73)$ & $(5.79)$ & $(5.73)$ & $(568)$ & $(3.96)$ & $(3.99)$ & & $(3.82)$ \\
\hline \multirow{2}{*}{$\begin{array}{l}\text { Agriculture share of } \\
\text { employment }\end{array}$} & $-0.4149 * * *$ & $-0.4132 * * *$ & $-0.4160 * * *$ & $-0.416 * * *$ & $-0.4602 * *$ & $-0.4462 * *$ & $-0.4352 * *$ & $-0.4313 * *$ \\
\hline & $(-7.29)$ & $(-7.59)$ & $(-7.48)$ & $(-7.35)$ & $(-2.29)$ & $(-2.18)$ & $(-2.16)$ & $(-2.15$ \\
\hline \multirow{2}{*}{$\begin{array}{l}\text { Other primary share of } \\
\text { employment }\end{array}$} & $-0.5261 * * *$ & $-0.5289 * * *$ & $-0.5273 * * *$ & $-0.5164 * * *$ & 0.19423 & 0.20121 & 0.19619 & 0.2097 \\
\hline & $(-4.85)$ & $(-4.92)$ & $(-4.94)$ & $(-4.76)$ & $(0.75)$ & $(0.77)$ & $(0.76)$ & $(0.81)$ \\
\hline \multirow{4}{*}{$\begin{array}{l}\text { Manufacturing share of } \\
\text { employment } \\
\% \text { Nonfarm self-employment }\end{array}$} & $-0.2694 * * *$ & $-0.2678 * * *$ & $-0.2702 * * *$ & $-0.2759 * * *$ & 0.06488 & 0.10473 & 0.12038 & 0.11051 \\
\hline & $(-3.53)$ & $(-3.53)$ & $(-3.55)$ & $(-3.59)$ & $(0.28)$ & $(0.46)$ & & $(0.48)$ \\
\hline & 0.06592 & 0.06384 & 0.06162 & 0.06193 & $0.5188 * *$ & $0.5227 * *$ & $0.5048 * *$ & $0.5185^{*}$ \\
\hline & $(0.71)$ & $(0.69)$ & $(0.67)$ & $(0.67)$ & & $(2.14)$ & & $(2.14)$ \\
\hline \multirow[t]{2}{*}{$\%$ with university degree } & 0.09669 & 0.1063 & 0.10652 & 0.11331 & -0.06925 & -0.08084 & -0.06912 & -0.0671 \\
\hline & $(0.51)$ & $(0.56)$ & $(0.56)$ & $(0.6)$ & $(-0.45)$ & $(-0.52)$ & $(-0.44)$ & $(-0.42)$ \\
\hline \multirow[t]{2}{*}{$\%$ of aboriginal origin } & $0.15896^{*}$ & $0.16306^{*}$ & $0.16293 *$ & 0.15442 & $0.29532 *$ & $0.32172 * *$ & $0.32199 * *$ & $0.32309 * *$ \\
\hline & $(1.70)$ & $(1.74)$ & & & & $(2.03)$ & & $(2.04$ \\
\hline \multirow[t]{2}{*}{ July relative humidity } & -0.00003 & -0.00004 & -0.00003 & 0.00001 & $0.00094 * *$ & $0.00095 * *$ & $0.0009 *$ & $0.00093 * *$ \\
\hline & $(-0.08)$ & $(-0.13)$ & $(-0.07)$ & & $(2.00)$ & $(2.04)$ & & $(2.01)$ \\
\hline \multirow[t]{2}{*}{ January average temperature } & $0.00262 * *$ & $0.00262 * *$ & $0.00258 * *$ & $0.0025 * *$ & -0.00182 & $-0.0022 * *$ & $-0.00214 * *$ & $-0.0021 *$ \\
\hline & $(2.60)$ & $(2.52)$ & $(2.49)$ & $(2.45)$ & $(-1.64)$ & $(-2.09)$ & $(-2.00)$ & $(-1.98)$ \\
\hline \multirow[t]{2}{*}{ Cinemas per capita } & $334 *$ & $331 *$ & $333 *$ & 213 & 30 & 28 & 43 & 41 \\
\hline & $(1.98)$ & $(1.96)$ & $(1.98)$ & $(1.37)$ & $(0.77)$ & $(0.79)$ & $(1.08)$ & $(1.05)$ \\
\hline$R^{2}$ & 0.3159 & 0.3148 & 0.3157 & 0.3185 & 0.4834 & 0.4813 & 0.4787 & 0.4777 \\
\hline
\end{tabular}

Notes: ${ }^{\mathrm{a}-\mathrm{b}}$ see Table 1; Constant term and provincial dummies included, not shown.

data into five regions ${ }^{16}$ : British Columbia (BC); Saskatchewan, Manitoba, and Alberta (Prairies);Newfoundland and Labrador, Prince Edward Island, Nova Scotia and New Brunswick (Atlantic Canada); Quebec; and Ontario.

The results for rural and urban communities (not shown) revealed an impact of co-op membership by region very similar to that at the national level, with few variations. For example,

\footnotetext{
${ }^{16}$ Aside from these being standard economic regions in Canada, there are also province-specific characteristics; for example, the co-operative sector in Quebec is organized differently than in the rest of Canada (Fulton 1990).
}

(C) Southern Regional Science Association, 2010. 
per capita co-op membership had a positive though not a significant impact on community population growth for both the rural and urban samples only in the prairie region, where the per capita co-op membership is the highest in Canada. Another variation was that co-op membership had a positive coefficient in the urban Quebec sample.

The results (not shown) for community population growth determinants by co-op industry category (agriculture, retail, housing, and "other services") also confirmed national level results with few exceptions. ${ }^{17}$ For example, higher per capita co-op membership in retail co-ops has a positive impact on population growth in urban communities, as does co-op membership in "other service" co-ops in surrounding communities; housing co-op membership in surrounding communities exerts a positive influence on community growth in rural areas only. By industry, as was the case at the aggregate national level for co-op types and for regions, co-ops do not appear to generate positive externalities in terms of making their rural communities more attractive places for population growth and retention. As many rural communities face population loss or stagnation as their economic bases decline and population concentrates in urban centers, there is no evidence that higher levels of social capital as represented by co-op membership ameliorates this trend.

\subsection{Sensitivity Analysis}

Table 3 replicates the national results from Table 1 (cols. 1, 5), along with a number of sensitivity runs. Even though 1991 predetermined values for the explanatory variables are used in our explanations of subsequent population growth, some endogeneity concerns may remain. Introducing longer lags further reduces the potential concerns of simultaneity or reverse causality between the population growth and the explanatory variables including co-op activity. Population change 1981-1991 was added (\% \%81-91pop) as an explanatory variable (cols. 2, 6), to assess whether past or persistent population growth trends are driving our results. That is, if co-ops are predominant in communities that have long been undergoing population decline, the lagged dependent variable should capture this effect, leaving other explanatory variables, including co-op activity, to pick up their own marginal contribution. The results in Table 3 showed no such pattern. ${ }^{18}$ We thus infer that the persistent lack of significance of the co-op membership variable is not due to co-op activity being associated with communities experiencing long term population decline.

Another sensitivity analysis was undertaken to assess if lagging the socio-economic variables by 10 years might affect the results. In this regression the 1991-2001 population change in the base model is expressed as a function of 1981 economic variables (cols. 3, 7). Following Glaeser et al. (1995), such deep lags, especially the share with a completed high school education, influence later growth. The results suggest no major differences from the base model, with the possible exception that there is an increase in significance, especially of agglomeration factors. We attribute this to the fact that the impact of these variables on population growth may take a long time to be fully realized. A final sensitivity estimation to test the importance of a lag structure was undertaken using 1996-2001 change in population as the dependent variable with 1991 explanatory variables (cols. 4, 8). No positive link between co-op activity and community population growth emerged.

\footnotetext{
${ }^{17}$ These are not "Co-op types" as above but rather the sectors within which any co-op may function. A producer co-op could be in the agriculture sector or in the housing sector, for example.

${ }^{18}$ The correlation between 1981-91 population change and per capita membership was .14 for rural CCSs and .12 for urban.

(C) Southern Regional Science Association, 2010.
} 
TABLE 3. Rural and Urban Percentage Change in Population for 1991-2001: Sensitivity Analysis ${ }^{\mathrm{a}, \mathrm{b}}$

\begin{tabular}{|c|c|c|c|c|c|c|c|c|}
\hline \multirow[b]{2}{*}{ Variables $^{c}$} & \multicolumn{4}{|c|}{ Rural } & \multicolumn{4}{|c|}{ Urban } \\
\hline & $91-01$ & $\begin{array}{c}\text { Lagged pop } \\
\text { change } 81-91\end{array}$ & $\begin{array}{c}\text { Lagged Econ } \\
\text { vars., ' } 81\end{array}$ & $\begin{array}{l}\text { Dep. var. } \\
96-01 \% \Delta\end{array}$ & $91-01$ & $\begin{array}{c}\text { Lagged pop } \\
\text { change 81-91 }\end{array}$ & $\begin{array}{c}\text { Lagged Econ } \\
\text { vars., ' } 81\end{array}$ & $\begin{array}{l}\text { Dep. var. } \\
96-01 \% \Delta\end{array}$ \\
\hline Dist. to nearest CMA, pop. $100 \mathrm{k}$ & $\begin{array}{r}-0.0002 \\
(-4.01)^{* * *}\end{array}$ & $\begin{array}{r}-0.0002 \\
(-3.87)^{* * *}\end{array}$ & $\begin{array}{r}-0.0002 \\
(-3.81)^{* * *}\end{array}$ & $\begin{array}{r}-0.0001 \\
(-4.18) * * *\end{array}$ & $\begin{array}{r}-0.00029 \\
(-4.32) * * *\end{array}$ & $\begin{array}{r}-0.0003 \\
(-4.40) * * *\end{array}$ & $\begin{array}{r}-0.0004 \\
(-4.16) * * *\end{array}$ & $\begin{array}{r}-0.0001 \\
(-2.56)^{* *}\end{array}$ \\
\hline Incr. dist. to CMA, pop. $250 \mathrm{k}$ & $\begin{array}{r}-0.00007 \\
(-1.66)^{*}\end{array}$ & $\begin{array}{r}-7.40 \mathrm{E}-05 \\
(-1.69)^{*}\end{array}$ & $\begin{array}{r}-8.70 \mathrm{E}-05 \\
(-1.99)^{* *}\end{array}$ & $\begin{array}{r}-2.20 \mathrm{E}-05 \\
(-0.65)\end{array}$ & $\begin{array}{l}-0.00011 \\
(-2.29)^{* *}\end{array}$ & $\begin{array}{r}-0.0001 \\
(-2.40)^{* *}\end{array}$ & $\begin{array}{r}-0.0002 \\
(-2.77)^{* * *}\end{array}$ & $\begin{array}{r}-0.0001 \\
(-1.63)\end{array}$ \\
\hline Incr. distance to CMA, pop. $500 \mathrm{k}$ & $\begin{array}{r}-0.00023 \\
(-2.85) * * *\end{array}$ & $\begin{array}{r}-0.0002 \\
(-2.72) * * *\end{array}$ & $\begin{array}{r}-0.0003 \\
(-3.18)^{* * *}\end{array}$ & $\begin{array}{r}-0.0002 \\
(-2.83) * * *\end{array}$ & $\begin{array}{r}0.00009 \\
(0.58)\end{array}$ & $\begin{array}{r}0.0001 \\
(0.48)\end{array}$ & $\begin{array}{r}-0.0001 \\
(-0.7)\end{array}$ & $\begin{array}{r}8.64 \mathrm{E}-05 \\
(1.4)\end{array}$ \\
\hline Nearest/own CMA Pop., 1981 & $\mathrm{n} / \mathrm{a}$ & $\mathrm{n} / \mathrm{a}$ & $\begin{array}{r}2.35 \mathrm{E}-08 \\
(2.45)^{* *}\end{array}$ & $\mathrm{n} / \mathrm{a}$ & $\mathrm{n} / \mathrm{a}$ & $\mathrm{n} / \mathrm{a}$ & $\begin{array}{r}2.25 \mathrm{E}-08 \\
(2.33)^{* *}\end{array}$ & $\mathrm{n} / \mathrm{a}$ \\
\hline Nearest/own CMA Pop., 1991 & $\begin{array}{l}1.64 \mathrm{E}-08 \\
(2.18)^{* *}\end{array}$ & $\begin{array}{r}1.62 \mathrm{E}-08 \\
(2.20)^{* *}\end{array}$ & & $\begin{array}{r}2.87 \mathrm{E}-09 \\
(0.93)\end{array}$ & $\begin{array}{c}1.52 \mathrm{E}-08 \\
(2.35)^{* *}\end{array}$ & $\begin{array}{c}1.37 \mathrm{E}-08 \\
(2.28)^{* *}\end{array}$ & $\mathrm{n} / \mathrm{a}$ & $\begin{array}{r}4.89 \mathrm{E}-09 \\
(1.16)\end{array}$ \\
\hline Pop. surrounding CCSs 1991 & $\begin{array}{r}2.80 \mathrm{E}-07 \\
(3.93) * * *\end{array}$ & $\begin{array}{r}2.82 \mathrm{E}-07 \\
(3.98)^{* * *}\end{array}$ & $\begin{array}{r}4.16 \mathrm{E}-07 \\
(4.25)^{* * *}\end{array}$ & $\begin{array}{r}1.03 \mathrm{E}-07 \\
(2.48)^{* *}\end{array}$ & $\begin{array}{r}-9.46 \mathrm{E}-09 \\
(-0.84)\end{array}$ & $\begin{array}{r}-4.51 \mathrm{E}-09 \\
(-0.4)\end{array}$ & $\begin{array}{r}-1.93 \mathrm{E}-08 \\
(-1.28)\end{array}$ & $\begin{array}{r}4.89 \mathrm{E}-09 \\
(1.47)\end{array}$ \\
\hline Population of the CCS, 1981 & $\mathrm{n} / \mathrm{a}$ & $\mathrm{n} / \mathrm{a}$ & $\begin{array}{r}1.08 \mathrm{E}-07 \\
(-0.09)\end{array}$ & $\mathrm{n} / \mathrm{a}$ & $\mathrm{n} / \mathrm{a}$ & $\mathrm{n} / \mathrm{a}$ & $\begin{array}{r}-8.02 \mathrm{E}-08 \\
(-0.79)\end{array}$ & $\mathrm{n} / \mathrm{a}$ \\
\hline $\begin{array}{l}\text { Pop. Chg. } \\
1981-91\end{array}$ & $\mathrm{n} / \mathrm{a}$ & $\begin{array}{r}0.0565 \\
(1.14)\end{array}$ & $\mathrm{n} / \mathrm{a}$ & $\mathrm{n} / \mathrm{a}$ & $\mathrm{n} / \mathrm{a}$ & $\begin{array}{l}-0.0812 \\
(-1.92)^{*}\end{array}$ & $\mathrm{n} / \mathrm{a}$ & $\mathrm{n} / \mathrm{a}$ \\
\hline Co-op Memb. per capita & $\begin{array}{r}-0.00879 \\
(-1.02)\end{array}$ & $\begin{array}{r}-0.0077 \\
(-0.88)\end{array}$ & $\begin{array}{r}-0.0086 \\
(-1.03)\end{array}$ & $\begin{array}{r}-0.0041 \\
(-0.77)\end{array}$ & $\begin{array}{r}-0.01513 \\
(-0.48)\end{array}$ & $\begin{array}{r}-0.0189 \\
(-0.61)\end{array}$ & $\begin{array}{l}-0.0547 \\
(-1.76)^{*}\end{array}$ & $\begin{array}{r}5.67 \mathrm{E}-04 \\
(1.05)\end{array}$ \\
\hline Co-op Memb./ capita, surr. & $\begin{array}{l}-0.03992 \\
(-2.04) * *\end{array}$ & $\begin{array}{l}-0.0373 \\
(-1.91)^{*}\end{array}$ & $\begin{array}{r}-0.063 \\
(-2.78) * * *\end{array}$ & $\begin{array}{r}-0.0086 \\
(-0.52)\end{array}$ & $\begin{array}{r}0.03688 \\
(0.92)\end{array}$ & $\begin{array}{l}0.0424 \\
(-1.04)\end{array}$ & $\begin{array}{r}0.015 \\
(0.25)\end{array}$ & $\begin{array}{r}0.0028 \\
(0.09)\end{array}$ \\
\hline Employment rate & $\begin{array}{r}0.25442 \\
(5.70)^{* * *}\end{array}$ & $\begin{array}{r}0.2037 \\
(3.49)^{* * *}\end{array}$ & $\begin{array}{r}0.1714 \\
(2.79)^{* * *}\end{array}$ & $\begin{array}{r}0.1052 \\
(3.26)^{* * *}\end{array}$ & $\begin{array}{r}0.3441 \\
(3.93)^{* * *}\end{array}$ & $\begin{array}{r}0.4152 \\
(6.72)^{* * *}\end{array}$ & $\begin{array}{r}0.0792 \\
(0.56)\end{array}$ & $\begin{array}{l}0.0405 \\
(-1.12)\end{array}$ \\
\hline Agriculture Share of Empl. & $\begin{array}{r}-0.41137 \\
(-7.32)^{* * *}\end{array}$ & $\begin{array}{r}-0.3735 \\
(-5.34)^{* * *}\end{array}$ & $\begin{array}{r}-0.3286 \\
(-5.00) * * *\end{array}$ & $\begin{array}{r}-0.1482 \\
(-3.37) * * *\end{array}$ & $\begin{array}{r}-0.4468 \\
(-2.21)^{* *}\end{array}$ & $\begin{array}{r}-0.4235 \\
(-2.46)^{* *}\end{array}$ & $\begin{array}{r}-0.2373 \\
(-1.6)\end{array}$ & $\begin{array}{r}-0.0199 \\
(-0.25)\end{array}$ \\
\hline Other primary Share of Empl. & $\begin{array}{r}-0.52944 \\
(-4.89)^{* * *}\end{array}$ & $\begin{array}{r}-0.5183 \\
(-4.57)^{* * *}\end{array}$ & $\begin{array}{r}-0.6457 \\
(-6.77)^{* * *}\end{array}$ & $\begin{array}{r}-0.2642 \\
(-3.07) * * *\end{array}$ & $\begin{array}{r}0.21609 \\
(0.83)\end{array}$ & $\begin{array}{r}0.1825 \\
(0.75)\end{array}$ & $\begin{array}{r}-0.2749 \\
(-1.37)\end{array}$ & $\begin{array}{r}0.0995 \\
(0.76)\end{array}$ \\
\hline Manufacturing Share of Empl. & $\begin{array}{r}-0.26696 \\
(-3.50)^{* * *}\end{array}$ & $\begin{array}{r}-0.2484 \\
(-3.16)^{* * *}\end{array}$ & $\begin{array}{r}-0.2728 \\
(-3.51)^{* * *}\end{array}$ & $\begin{array}{r}-0.0605 \\
(-0.97)\end{array}$ & $\begin{array}{r}0.09266 \\
(0.4)\end{array}$ & $\begin{array}{r}0.1104 \\
(0.5)\end{array}$ & $\begin{array}{r}-0.4924 \\
(-2.08)^{* *}\end{array}$ & $\begin{array}{r}0.0538 \\
(0.54)\end{array}$ \\
\hline$\%$ Nonfarm self employment & $\begin{array}{r}0.06685 \\
(0.73)\end{array}$ & $\begin{array}{r}0.0647 \\
(0.71)\end{array}$ & $\begin{array}{r}0.024 \\
(0.25)\end{array}$ & $\begin{array}{r}0.0394 \\
(0.72)\end{array}$ & $\begin{array}{r}0.5148 \\
(2.11)^{* *}\end{array}$ & $\begin{array}{r}0.468 \\
(1.98)^{*}\end{array}$ & $\begin{array}{r}0.0837 \\
(0.4)\end{array}$ & $\begin{array}{r}-0.0324 \\
(-0.32)\end{array}$ \\
\hline$\%$ of Aboriginal Origin & $\begin{array}{r}0.15736 \\
(1.68)^{*}\end{array}$ & $\begin{array}{r}0.1447 \\
(1.53)\end{array}$ & $\begin{array}{r}0.226 \\
(1.95)^{*}\end{array}$ & $\begin{array}{c}0.1116 \\
(1.72)^{*}\end{array}$ & $\begin{array}{l}0.32286 \\
(2.05)^{* *}\end{array}$ & $\begin{array}{r}0.3663 \\
(2.21)^{* *}\end{array}$ & $\begin{array}{r}0.2133 \\
(1.55)\end{array}$ & $\begin{array}{r}-0.0189 \\
(-0.26)\end{array}$ \\
\hline July relative humidity & $\begin{array}{r}-0.00003 \\
(-0.09)\end{array}$ & $\begin{array}{r}-0.0001 \\
(-0.15)\end{array}$ & $\begin{array}{r}0.0002 \\
(0.54)\end{array}$ & $\begin{array}{r}-0.0002 \\
(-0.6)\end{array}$ & $\begin{array}{r}0.00093 \\
(1.98)^{*}\end{array}$ & $\begin{array}{r}0.0011 \\
(2.23)^{* *}\end{array}$ & $\begin{array}{r}0.0002 \\
(0.33)\end{array}$ & $\begin{array}{r}0.0012 \\
(3.21)^{* * *}\end{array}$ \\
\hline January average temperature & $\begin{array}{l}0.00262 \\
(2.61)^{* *}\end{array}$ & $\begin{array}{r}0.0026 \\
(2.53)^{* *}\end{array}$ & $\begin{array}{r}0.0024 \\
(2.28)^{* *}\end{array}$ & $\begin{array}{c}0.0012 \\
(1.86)^{*}\end{array}$ & $\begin{array}{l}-0.0021 \\
(-1.97)^{*}\end{array}$ & $\begin{array}{r}-0.0018 \\
(-1.66)\end{array}$ & $\begin{array}{r}-0.0008 \\
(-0.53)\end{array}$ & $\begin{array}{r}-0.0014 \\
(-1.5)\end{array}$ \\
\hline Cinemas per capita & $\begin{array}{r}334 \\
(1.95)^{*}\end{array}$ & $\begin{array}{r}351 \\
(2.12)^{* *}\end{array}$ & $\begin{array}{r}391 \\
(2.25)^{* *}\end{array}$ & $\begin{array}{r}92 \\
(0.83)\end{array}$ & $\begin{array}{r}35 \\
(0.9)\end{array}$ & $\begin{array}{r}-36 \\
(-0.97)\end{array}$ & $\begin{array}{r}-4 \\
(-0.12)\end{array}$ & $\begin{array}{r}13 \\
(0.89)\end{array}$ \\
\hline Outpatient Clinics per capita & $\begin{array}{r}-10 \\
(-0.63)\end{array}$ & $\begin{array}{r}-1 \\
(-0.79)\end{array}$ & $\begin{array}{r}-6 \\
(-0.32)\end{array}$ & $\begin{array}{r}9 \\
(0.48)\end{array}$ & $\begin{array}{r}-134 \\
(-0.76)\end{array}$ & $\begin{array}{r}-143 \\
(-0.82)\end{array}$ & $\begin{array}{r}-120 \\
(-0.67)\end{array}$ & $\begin{array}{r}-44 \\
(-0.61)\end{array}$ \\
\hline $\begin{array}{l}\text { Observations } \\
\text { R-squared }\end{array}$ & $\begin{array}{r}1995 \\
0.3163\end{array}$ & $\begin{array}{r}1995 \\
0.3178\end{array}$ & $\begin{array}{r}1999 \\
0.2934\end{array}$ & $\begin{array}{r}1990 \\
0.1841\end{array}$ & $\begin{array}{r}510 \\
0.4786\end{array}$ & $\begin{array}{r}510 \\
0.488\end{array}$ & $\begin{array}{r}510 \\
0.2085\end{array}$ & $\begin{array}{r}510 \\
0.3454\end{array}$ \\
\hline
\end{tabular}

Notes: ${ }^{\mathrm{a}}$ See Table 1; Constant term and provincial dummies included, not shown. ${ }^{\mathrm{b}} \mathrm{n} / \mathrm{a}$ denotes the variable does not apply.

\subsection{Performance of Co-op Variables}

Given our expectations of the positive contribution of co-op involvement in community economic growth and retention and of the sheer mass of literature that generally supports this perspective, some postulated rationales for our findings seem warranted. Possible explanations include: 
- Co-op activity substitutes for private sector activity or for other forms of social capital, thus making no net contribution to community growth, though it may have other effects.

- Producer co-operatives in rural communities were formed to offer solutions to various marketing and input-supply problems at the beginning of the $20^{\text {th }}$ century; their organization, values and objectives are less relevant in the global, knowledge-based economy.

- Co-ops may be performing services for their membership and pursuing goals unrelated to population retention or attraction.

- Negative impacts of social capital, such as exclusion or discrimination against outsiders or new ideas, may be offsetting their positive influences.

In any case, the interpretation of the results must be limited to the role of co-operatives. While we have posited that they represent social capital, the results do not necessarily generalize to all social capital.

\section{CONCLUSION}

Community commitments, trust, and networks that characterize social capital and that are consistent with the development of co-operatives may be expected to make rural communities more attractive to households and businesses. Nonetheless, in our models of population change, after controlling for the prevailing socio-economic and spatial attributes of the communities, there is little evidence of this. In national, as well as co-op type and regional and industry type models, co-op membership does not make a positive contribution to rural community population growth, with a couple of minor exceptions.

The social economy has recently been hailed in Canada as a positive contributor to community economic growth and vitality. It is proposed that through building on and producing social capital, the social economy may be particularly important for rural development. Cooperatives are often proposed as the vehicle by which this may occur. Findings to the contrary in our study suggest that there is need for further research. One possible area of pursuit is a better articulation of the nature of the social capital embodied in the social economy structures. It may be that over time some social capital becomes a barrier to innovation or to broadening the markets or capacity beyond the particular site of the social capital. Another area for further research is an assessment of whether co-ops crowd out private enterprises, with specific attention to the types of sectors.

Within the aggregate of social capital, co-ops may substitute for other types of social capital that may be more influential in making communities attractive for population growth and retention. More research is required to investigate why co-ops are not playing this role in their communities. Indeed, it is possible that co-ops could have other social goals that take precedence over goals related to broader community development. A similar assessment using co-ops in other countries would also be useful because their histories and goals may differ-e.g., France or the United States. Ideally an investigation of the relationship between co-operatives and regional economic growth would be conducted over a longer period of time with a panel data set that would allow controlling for the effect of past changes and past fixed effects on current relationships. In addition, a more complete articulation of the social capital aspects of co-op activity and membership would permit an assessment of our assumption that co-ops perform a form of social capital function. Finally, in terms of this particular study, the addition of financial 
co-operatives would be of value in assessing more completely the role of co-operatives in community economic development.

\section{REFERENCES}

Agriculture and Agri-Food Canada (AAFC). (2002) "Canadian Rural Population Trends," Rural Research Note. Government of Canada. November.

. (2008) About Co-ops in Canada. Available at: http://www.coop.gc.ca/COOP/, October.

Birch, Kean and Geoff Whittam. (2008) "The Third Sector and the Regional Development of Social Capital," Regional Studies, 42, 437-450.

Birchall, Johnston. (1997) The International Co-operative Movement. Manchester University Press: Oxford, UK.

Bollman, Ray D. (2006) "Rural Canada: Drivers and Riders," Presentation to the Growing Regions Conference, July 2006, Brisbane, Australia.

Bollman, Ray D. and Robert Mendelson. (1998) "Rural and Small Town Population is Growing in the 1990s," Rural and Small Town Canada Analysis Bulletin, Vol. 1 No 1 Catalogue no.21-006 XIE. Available at: http://www.statcan.ca/english/freepub/21-006-XIE/21-006XIE1998001.pdf, January.

Chou, Yuan K. (2006) “Three Simple Models of Social Capital and Economic Growth,” Journal of Socio-Economics, 35, 889-912.

Craig, John G. (1993) The Nature of Co-operation. Black Rose Books: Montreal.

DeFilippis, James. (2001) "The Myth of Social Capital in Community Development," Housing Policy Debate, 12, 781-806.

Deller, Steven C., Tsung-Hsiu (Sue) Tsai, David W. Marcouiller and Donald B. K. English. (2001) "The Role of Amenities and Quality of Life in Rural Economic Growth," American Journal of Agricultural Economics, 83, 352-365.

Durlauf, Steven N. (1999) "The Case "Against" Social Capital," Wisconsin Madison - Social Systems Working Paper 29. University of Wisconsin, Madison.

. (2002) "On the Empirics of Social Capital," Economic Journal, 112, 459-479.

Durlauf, Steven N. and Marcel Fafchamps. (2004) "Social Capital," NBER Working Paper Series 10485: Cambridge, MA.

Evans, Mel and Stephen Syrett. (2007) "Generating Social Capital: The Social Economy and Local Economic Development," European Urban and Regional Studies, 14, 55-74.

Fairbairn, Brett. (2005) "Canada's Co-operative Province. Individualism and Mutualism in a Settler Society 1905-2005," Centre for the Study of Cooperatives Occasional Paper Series. University of Saskatchewan: Saskatoon, SK.

. (2001) "The Co-operative Tradition in Canada," In John Restakis and Evert A. Lidquist (eds), The Co-op Alternative. Civil Society and the Future of Public Services. Institute of Public Administration of Canada: Toronto, ON, pp. 31-51. 
- (1990) "Social Bases of Co-operation: Historical Examples and Contemporary Questions," In Murray E. Fulton (ed), Co-operative Organizations and Canadian Society: Popular Institutions and Dilemmas of Change. University of Toronto Press: Toronto, ON, pp. 63-76.

Fairbairn, Brett, Christopher S. Axworthy, Murray Fulton, Lou H. Ketilson, and David Laycock. (1990) "Co-operative Institutions: Five Disciplinary Perspectives," In Murray E. Fulton (ed), Co-operative Organizations and Canadian Society: Popular Institutions and Dilemmas of Change. University of Toronto Press Toronto, ON, pp. 13-38.

Ferguson, Mark, Kamar Ali, Margaret R. Olfert, and Mark D. Partridge. (2007) "Voting with Their Feet: Jobs versus Amenities," Growth and Change, 38, 77-100.

Flora, Jan L. (1998) “Social Capital and Communities of Place,” Rural Sociology, 63, 481-506.

Fowke, Vernon C. (1973) The National Policy and the Wheat Economy. University of Toronto Press: Toronto, ON.

Fulton, Murray and Lou H. Ketilson. (1992) "The Role of Co-operatives in Communities: Examples from Saskatchewan," Journal of Agricultural Co-operatives, 7, 15-42.

Glaeser, Edward L., David Laibson, and Bruce Sacerdote. (2002) "An Economic Approach to Social Capital," Economic Journal, 112, F437-F458.

Glaeser, Edward L., Jed Kolko, and Albert Saiz. (2001) “Consumer City,” Journal of Economic Geography, 1, 27-50.

Goetz, Stephan and Anil Rupasingha. (2002) "High-Tech Firm Clustering: Implications for Rural Areas," American Journal of Agricultural Economics, 84, 1229-1236.

Gui, Benedetto. (2001) "The Economic Rationale for the Third Sector," Annals of Public and Co-operative Economics, 62, 551-572.

Human Resources and Social Development Canada (HRSDC). (2007) Social Economy: Questions and Answers. Available at http://www.hrsdc.gc.ca/eng/cs/comm/sd/ social_economy.shtml, November.

Kilkenny, Maureen, Laura Nalbarte, and Terry Besser. (1999) "Reciprocated Community Support and Small Town, Small Business Success," Entrepreneurship and Regional Development, 11, 231-246.

Knack, Stephen and Philip Keefer. (1997) "Does Social Capital Have an Economic Payoff? A Cross-Country Investigation,” Quarterly Journal of Economics, 112, 1251-1288.

Krugman, Paul. (1991) "Increasing Returns and Economic Geography," Journal of Political Economy, 99, 483-499.

MacPherson, Ian. (1979) Each for All. A History of the Co-operative Movement in English Canada, 1900-1945. Carleton University Press: Ottawa, ON.

McGranahan, David and Calvin L. Beale. (2002) "Understanding Rural Population Loss," Rural America, 17, 2-11.

Novkovic, Sonja. (2008) "Defining the Co-operative Difference," Journal of Socio-Economics, 37, 2168-2177.

(C) Southern Regional Science Association, 2010. 
Organization for Economic Co-operation and Development (OECD). (2003). The Non-Profit Sector in a Changing Economy. OECD Publications: Paris, France.

Partridge, Mark D., M. Rose. Olfert, and Alessandro Alasia. (2007a) "Agglomeration or Amenities: Canadian Cities as Engines of Growth," Canadian Journal of Economics, 40, 39-68.

Partridge, Mark D., Dan S. Rickman, Kamar Ali, and M. Rose Olfert. (2007b) "The Landscape of Urban Influence on U.S. County Job Growth," Review of Agricultural Economics, 29, 381-389.

. (2008) "Lost in Space: Population Dynamics in the American Hinterlands and Small Cities," Journal of Economic Geography, 8, 727-757.

Partridge, Mark D. and Dan S. Rickman. (2003) "Do We Know Economic Development When We See It?" Review of Regional Studies, 33, 17-39.

. (1996) "The Role of Industry Structure, Costs, and Economic Spillovers in Determining State Employment Growth Rates," Review of Regional Studies, 26, 235-264.

Putnam, Robert D. (1993) "The Prosperous Community_-Social Capital and Public Life," The American Prospect, 4(13), 35-42.

Putnam, Robert D. and John F. Helliwell. (1995) "Economic and Social Capital in Italy," Eastern Economic Journal, 21, 295-307.

Quarter, Jack. (1992) Canada's Social Economy. Co-operatives, Non-profits and Other Community Enterprises. James Lorimer and Company Publishers: Toronto, ON.

Reimer, Bill. (1997) "Informal Social Networks and Voluntary Associations in NonMetropolitan Canada," In Richard C. Rounds (ed), Changing Rural Institutions. A Canadian Perspective. Canadian Rural Restructuring Foundation in cooperation with the Rural Development Institute, Brandon University: Brandon, MB, pp. 89-104.

Restakis, John and Evert A. Lindquist. (2001) The Co-op Alternative, Civil Society and the Future of Public Services. The Institute of Public Administration of Canada: Toronto, ON.

Roback, Jennifer. (1982) "Wages, Rents, and the Quality of Life," Journal of Political Economy, $90,1257-1278$.

Rothwell, Neil, Ray D. Bollman, Juno Tremblay and Jeff Marshall. (2002) "Migration to and from Rural and Small Town Canada." Rural and Small Town Canada Analysis Bulletin 3 (March), 3(6), Catalogue no. 21-006-XIE.

Rupasingha, Anil, Stephan J. Goetz, and David Freshwater. (2000) "Social Capital and Economic Growth: A County-level Analysis," Journal of Agricultural and Applied Economics, 32, 565-572.

Sätre-Åhlander, Ann-Mari. (2001) "The Social Economy: New Co-operatives and Public Sector," Annals of Public and Co-operative Economics, 72, 413-433.

Simon, Curtis. (1998) "Human Capital and Metropolitan Employment Growth," Journal of Urban Economics, 43, 223-243.

(C) Southern Regional Science Association, 2010. 
Simbandumwe, Louise, Murray Fulton and Lou H. Ketilson. (1991) "The Co-operative Sector in Saskatchewan. A Statistical Overview," Occasional Paper Series. Centre for the Study of Co-operatives, University of Saskatchewan: Saskatoon, SK.

Turcotte, Martin. (2005) "Social Engagement and Civic Participation: Are Rural and Small Town Populations Really at an Advantage?" Rural and Small Town Canada Analysis Bulletin, 6(4), Catalogue no. 21-006-XIE.

Voith, Richard. (1991) "Capitalization of Local and Regional Attributes into Wages and Rents: Differences across Residential, Commercial and Mixed-use Communities," Journal of Regional Science, 31, 127-145.

University of Wisconsin. (2005) A Glossary for Cooperatives. Bulletin \#10. University of Wisconsin, Center for the Study of Co-ops: Madison, WI.

Westlund, Hans. (2006) Social Capital in the Knowledge Economy: Theory and Empirics. Springer: Berlin and New York.

Woolcock, Michael. (2000) The Place of Social Capital in Understanding Social and Economic. Outcomes. Development Research Group, The World Bank and Kennedy School of Government, Harvard University. Available at http://www.oecd.org/dataoecd/5/13/ 1824913.pdf, February.

(C) Southern Regional Science Association, 2010. 
APPENDIX FIGURE A1. Per Capita Co-op Membership at the CCS Level, Canada 2006.
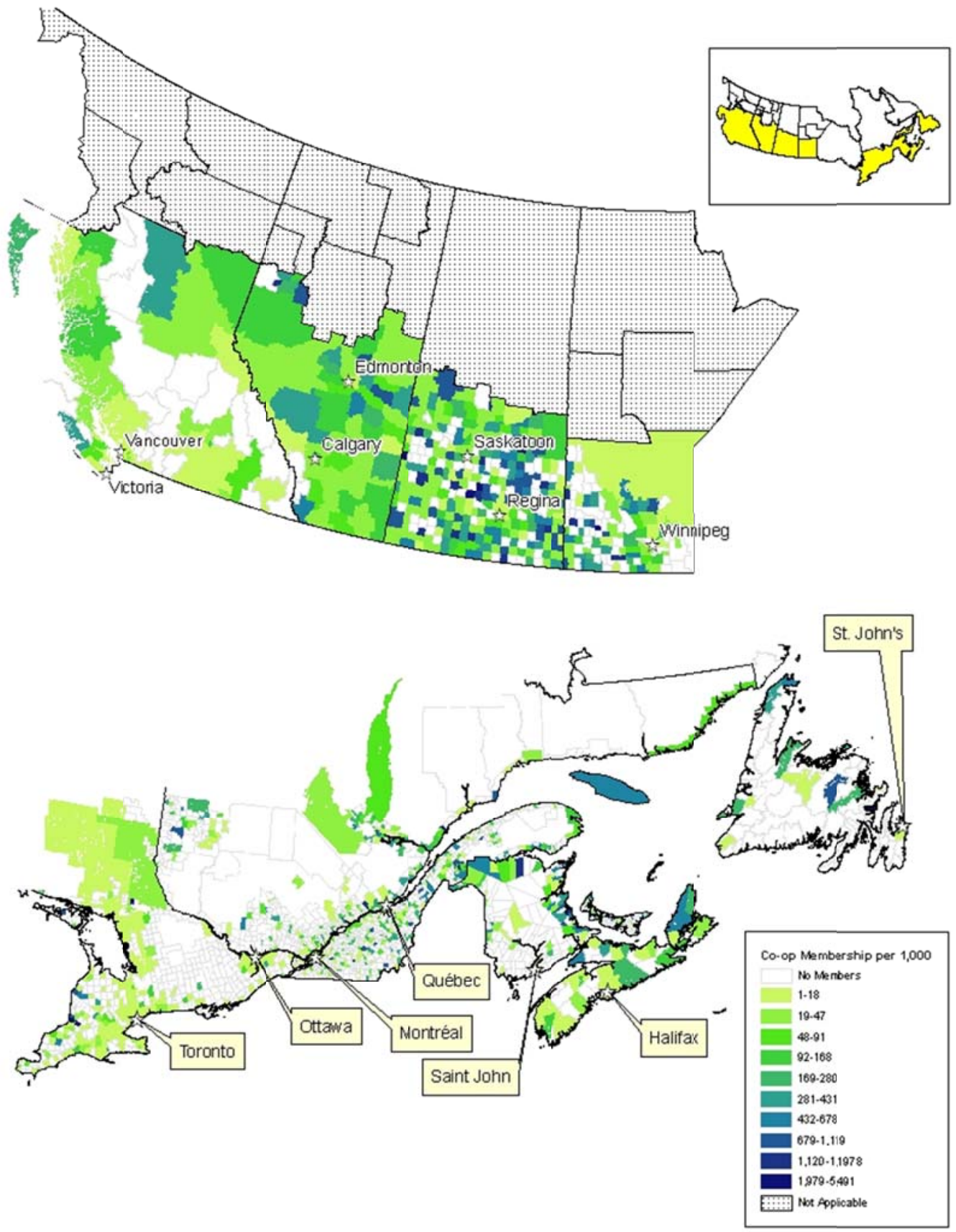

(C) Southern Regional Science Association, 2010. 


\section{APPENDIX TABLE A1. Descriptions of Variables and Data Sources}

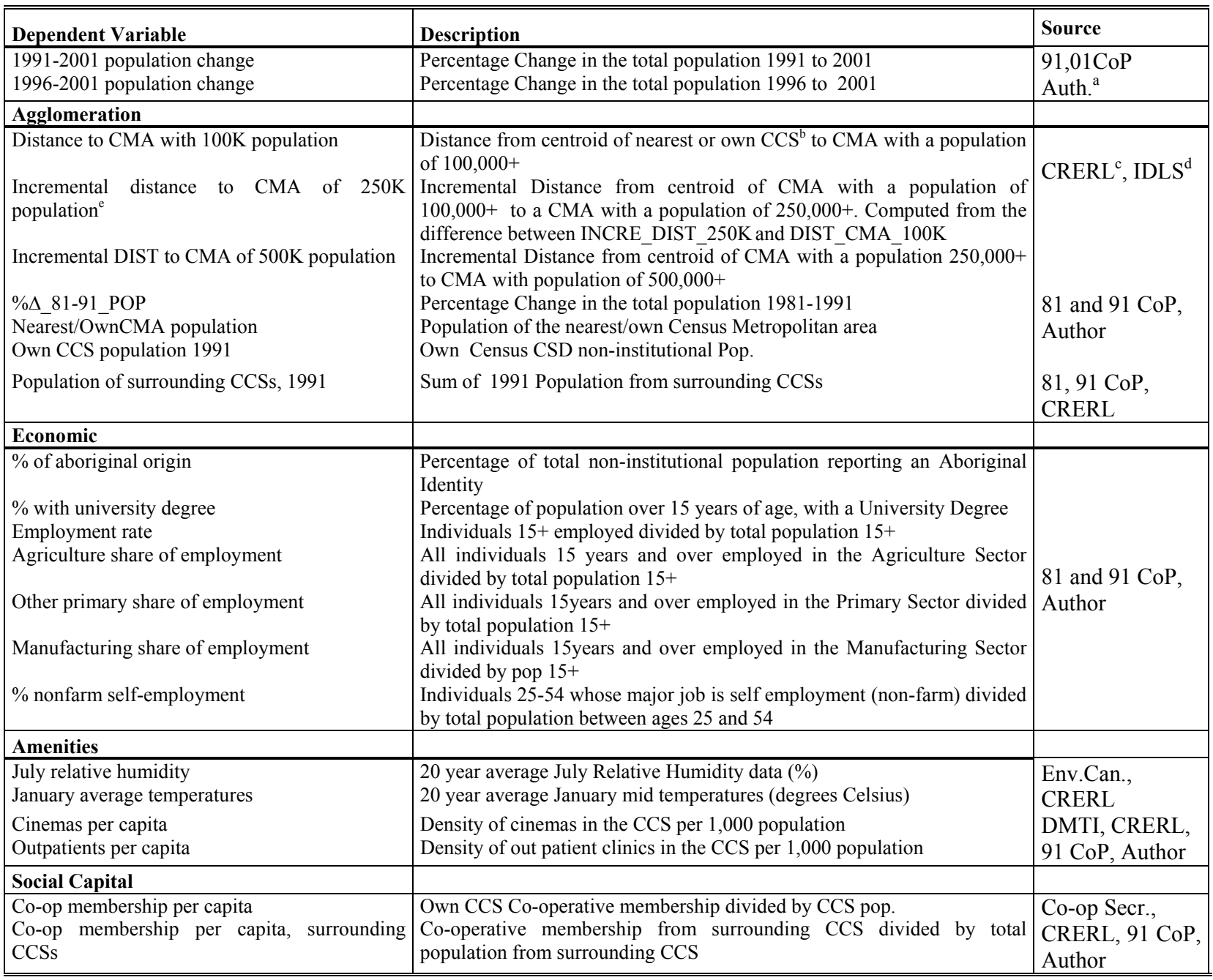

${ }^{\mathrm{a}}$ Author -denote data that was modified by the authors, CoP-Census of Population; ${ }^{\mathrm{b}} \mathrm{CCS}$ stands for Census Consolidated Subdivision, which is our unit of observation, see footnote 8 for description ; CRERL-Canada Rural Economy Research Lab (www.crerl.usask.ca) examines all issues that affect the vitality of Rural Canada from a diversified economy, healthcare, environment, amenities, transportation, to a productive and sustainable agricultural sector. ILDS - Internet Data Library System provided data that was used in the conversion of spatial data; ${ }^{\mathrm{d}}$ The variable INCRE_DIST was obtained by subtracting the distance to the nearest mega center from the distance to the nearest urban center; ${ }^{\mathrm{D}}$ Data to proxy for social capital was generated from the 1992 Co-operatives Secretariat yearly co-operative mail survey. 
APPENDIX TABLE 2: CCS Descriptive Statistics

\begin{tabular}{|c|c|c|c|c|}
\hline & \multicolumn{2}{|c|}{ Rural } & \multicolumn{2}{|c|}{ Urban } \\
\hline & Mean & Std. Dev & Mean & Std. Dev \\
\hline \multicolumn{5}{|l|}{ Population Change (1991-2001) } \\
\hline CANADA & -0.009 & 0.170 & 0.108 & 0.149 \\
\hline BRITISH COLUMBIA & 0.090 & 0.158 & 0.158 & 0.485 \\
\hline PRAIRIES & -0.067 & 0.163 & 0.105 & 0.140 \\
\hline ONTARIO & 0.058 & 0.211 & 0.125 & 0.151 \\
\hline QUEBEC & 0.006 & 0.179 & 0.104 & 0.258 \\
\hline ATLANTIC & -0.062 & 0.152 & 0.043 & 0.124 \\
\hline \multicolumn{5}{|l|}{ Population Change (1996-2001) } \\
\hline CANADA & -0.024 & 0.108 & 0.032 & 0.073 \\
\hline \multicolumn{5}{|l|}{ Agglomeration } \\
\hline Distance to nearest CMA, pop. $100 \mathrm{k}$ & 139.466 & 114.366 & 80.018 & 109.544 \\
\hline Incremental distance to CMA, pop. $250 \mathrm{k}$ & 104.070 & 153.075 & 73.286 & 128.893 \\
\hline Incremental distance to CMA, pop. $500 \mathrm{k}$ & 49.790 & 130.168 & 50.264 & 129.762 \\
\hline Nearest or own CMA population, 1991 & 581,372 & 886,499 & 936,410 & $1,222,055$ \\
\hline Population of surrounding CCSs 1991 & 27,394 & 45,333 & 222,338 & 410,127 \\
\hline Population of the CCS, 1991 & 2,770 & 3,770 & 41,723 & 112,297 \\
\hline \multicolumn{5}{|l|}{ Economic } \\
\hline$\%$ of aboriginal origin, 1991 & 0.044 & 0.110 & 0.035 & 0.054 \\
\hline$\%$ with university degree, 1991 & 0.046 & 0.036 & 0.108 & 0.076 \\
\hline Employment rate, 1991 & 0.559 & 0.162 & 0.764 & 0.247 \\
\hline Agriculture share of employment & 0.103 & 0.118 & 0.032 & 0.046 \\
\hline Other primary share of employment & 0.019 & 0.034 & 0.014 & 0.030 \\
\hline Manufacturing share of employment & 0.043 & 0.050 & 0.043 & 0.031 \\
\hline$\%$ nonfarm self-employment & 0.073 & 0.051 & 0.083 & 0.029 \\
\hline \multicolumn{5}{|l|}{ Amenities } \\
\hline July relative humidity & 58.522 & 9.346 & 58.439 & 9.217 \\
\hline January average temperature & -11.924 & 4.397 & -11.584 & 4.283 \\
\hline Cinemas per capita & $1.69 \mathrm{E}-06$ & $1.45 \mathrm{E}-05$ & $1.45 \mathrm{E}-05$ & $4.45 \mathrm{E}-05$ \\
\hline Outpatient clinics per capita & $4.25 \mathrm{E}-05$ & $2.06 \mathrm{E}-04$ & $8.75 \mathrm{E}-06$ & $5.75 \mathrm{E}-06$ \\
\hline \multicolumn{5}{|l|}{ Social Capital } \\
\hline \multicolumn{5}{|l|}{ Co-op membership per capita } \\
\hline CANADA & 0.109 & 0.294 & 0.063 & 0.172 \\
\hline BRITISH COLUMBIA & 0.039 & 0.027 & 0.033 & 0.158 \\
\hline PRAIRIES & 0.299 & 0.015 & 0.226 & 0.033 \\
\hline ONTARIO & 0.012 & 0.046 & 0.010 & 0.127 \\
\hline QUEBEC & 0.076 & 0.112 & 0.138 & 0.089 \\
\hline ATLANTIC & 0.073 & 0.751 & 0.044 & 0.251 \\
\hline Co-op membership, surrounding CCSs & 0.138 & 0.202 & 0.077 & 0.130 \\
\hline Consumer co-op membership per capita & 0.068 & 0.213 & 0.047 & 0.140 \\
\hline Consumer co-op/capita surrounding CCSs & 0.096 & 0.156 & 0.065 & 0.119 \\
\hline Producer co-op membership per capita & 0.002 & 0.019 & 0.000 & 0.001 \\
\hline Producer co-op/capita surrounding CCSs & 0.001 & 0.006 & 0.000 & 0.002 \\
\hline Worker co-op membership per capita & 0.022 & 0.111 & 0.007 & 0.039 \\
\hline Worker co-op/capita surrounding CCSs & 0.019 & 0.046 & 0.007 & 0.025 \\
\hline Other co-op membership per capita & $5.41 \mathrm{E}-05$ & $1.49 \mathrm{E}-03$ & $1.63 \mathrm{E}-04$ & $1.75 \mathrm{E}-03$ \\
\hline Other co-op/capita surrounding CCSs & $3.75 \mathrm{E}-04$ & 0.005 & 0.004 & 0.043 \\
\hline$N$ & \multicolumn{2}{|c|}{2,086} & \multicolumn{2}{|r|}{515} \\
\hline
\end{tabular}

C) Southern Regional Science Association, 2010. 